\title{
A poética do espaço, de Gaston Bachelard
}

\author{
Bárbara Silva \\ barbarasilva@gmail.com \\ Professora Auxiliar do Da/UAL | Professora convidada no Departamento de Arquitetura da FCT - \\ Universidade de Coimbra | Diretora da Galeria de arquitetura NOTE, em Lisboa.
}

Para citação: SILVA, Bárbara - A poética do espaço, de Gaston Bachelard. Estudo Prévio 17. Lisboa: CEACT/UAL - Centro de Estudos de Arquitetura, Cidade e Território da Universidade Autónoma de Lisboa, 2020. ISSN: 2182-4339 [Disponível em: www.estudoprevio.net]. DOI: https://doi.org/10.26619/2182-4339/17.01

Recensão recebida a 15 de julho de 2020 e aceite para publicação a 20 de julho de 2020.

Creative Commons, licence CC BY-4.0: https://creativecommons.org/licenses/by/4.0/

"A poética do espaço" (La Poétique de l'Espace) é um livro de 1958, escrito pelo
filósofo e poeta Francês Gaston Bachelard (1884-1962), que reflete sobre a
importância e o impacto do espaço do habitar no ser humano". Bachelard sugere que
espaços como o quarto, o porão, o sótão, ou espaços onde habitam as coisas, como
gavetas, cofres e armários, são espaços íntimos e abrigos ocasionais, capazes de
produzir sentimentos e lembranças, que são um importante instrumento de descoberta
do espírito e da alma humana ${ }^{2}$. Estes sentimentos e lembranças criam, segundo o
autor, imagens poéticas que, mesmo não sendo totalmente reais ou racionais, têm um
dinamismo próprio; elas são vividas "com todas as parcialidades da imaginação"
(p.196). Uma imaginação que "imagina incessantemente e se enriquece de novas
imagens. É essa a riqueza do ser imaginado que queremos explorar." (p. 196). Com
esta afirmação, que se pode ler na introdução, Bachelard anuncia que o livro será uma
viagem ao mundo das inúmeras imagens poéticas que podem surgir nos espaços de
intimidade da casa, sendo esta o lugar privilegiado para o sonho e para o devaneio.
Contudo, o seu objetivo não é entender a origem da imagem, mas sim provocar o
impacto da imagem no leitor, ou recetor. Mas, para que seja possível desvendar o
impacto das imagens poéticas, Bachelard adverte que o leitor deve esquecer toda a
cultura e todo o conhecimento adquirido no passado para que o seu corpo, a sua alma
e o seu espírito, sejam capazes de decifrar o significado dessas imagens que se
formam, inconscientemente, na sua mente: "Um filósofo que formou todo o seu
pensamento ligando-se aos temas fundamentais da filosofia e das ciências, que
seguiu, o mais precisamente possível, a linha do racionalismo activo, a linha do
racionalismo crescente da ciência contemporânea, deve esquecer o seu saber, romper 
com todos os hábitos de pesquisa filosóficas, se quiser estudar os problemas colocados pela imaginação poética" (p.183). Portanto, Bachelard sugere um modo para analisar algo (a imagem poética) que deve ser percebida na ausência de um método ou de um conhecimento. Defendendo que "a imagem, em sua simplicidade, não precisa de um saber. Ela é dádiva de uma consciência ingénua" (p.195). Ainda na introdução o autor faz uma breve explicação de cada capítulo (dez no total), e termina por revelar o seu objetivo: "No presente livro, o nosso campo de exame tem a vantagem de ser bem delimitado. Queremos examinar, com efeito, imagens bem simples, as imagens do espaço feliz" (p. 196).

No primeiro capítulo, intitulado "A casa. Do porão ao sótão. O sentido da cabana", Bachelard afirma que "A casa é o nosso canto no mundo. Ela é, como se diz frequentemente, o nosso primeiro universo. É um verdadeiro cosmos" (p. 200). Significa que todos os sonhos, as lembranças, os desejos, os medos e solidões que sentimos estão connosco, na casa: "a casa é o lugar mais poderoso de integração para os pensamentos, as lembranças, e os sonhos do homem. Nessa integração, o princípio que faz a ligação é o devaneio." (p. 201). Com esta frase Bachelard deixanos intuir que a casa é "um corpo de sonhos" (p. 207); um lugar que nos acolhe em nós mesmos, um lugar onde o medo e a solidão é constitutiva: "Feliz a criança que possui, realmente, as suas solidões!" (p. 207). Bachelard sugere que a casa é um lugar que permite o devaneio. E é nesse devaneio, de diferentes vivências do espaço íntimo da casa, onde somos capazes de conhecer o nosso verdadeiro eu.

"A Casa e o universo" é o título do segundo capítulo do livro. Aqui, o autor faz uma leitura lenta de alguns espaços da casa descritos por grandes escritores como Baudelaire, Rilke, Henri Bosco, Edgar Allan Poe. Bachelard é conduzido por imagens que foram criadas por outros, e não por ele. Por exemplo, na cabana de Thomas de Quincey, criada por Baudelaire, encontramos a casa como um espaço que abriga e protege "o nosso eu" das tempestades e adversidades externas: "Baudelaire sente o crescimento do valor da intimidade quando a casa é atacada pelo inverno" (p. 222), o que nos remete à imagem da cabana. Instintivamente somos assomados por imagens de tranquilidade, sonho e solidão; o que Bachelard chama de "devaneios de repouso" (p. 222). Pelo contrário, Rilke sustenta que para ele "é na cidade que a tempestade é ofensiva" (p.224). Rilke não teme a solidão do campo, mas sim o orgulho da cidade: "fico amedrontado na cidade por causa das borrascas noturnas (...) elas não nos vêm. Enquanto que uma casa solitária, no campo, elas (as casas) a vêm, tomando-a em seus braços poderosos (...)". Ou seja; Bachelard recorre a exemplos de outros pensadores, para mostrar que a cabana, tal como a casa (mas de maneira diferente), é um instrumento que serve para enfrentar o nosso cosmos: "Nessa comunhão dinâmica do homem e da casa, nessa rivalidade da casa e do universo, estamos longe de qualquer referência às simples formas geométricas. A casa vivida não é uma caixa inerte. O espaço habitado transcende o espaço geométrico" (p. 225). Neste capítulo, Bachelard continua a dar destaque à casa como o lugar de proteção que abriga o devaneio e permite sonhar em paz, referindo-se à cabana como o abrigo que luta contra as tempestades "como uma loba" (p. 226) para defender o seu morador que, apesar de todas as agressividades exteriores, se sente protegido e acolhido por aquela entidade que, perante as agressividades, se transforma numa fortaleza de coragem. E assim, "o heroísmo da casa passa a habitar a fragilidade do homem" (p. 227).

No capítulo três: "A gaveta, os cofres e os armários" Bachelard fala, recorrentemente através de metáforas, sobre os espaços onde habitam as coisas. Aqui são várias a 
referências a artistas, como André Breton, que têm a capacidade de ouvir as "maravilhas do irreal" ( $p$.249): "O armário está cheio de roupa limpa. Há até raios de lua que posso desdobrar" (p. 249). Bachelard está a evocar, através de Breton, o mundo do surrealismo. O mundo onírico; o mundo dos sonhos. Novamente fala-nos sobre o poder dos sonhos para o deleite da imaginação e do devaneio: "Abre-se o móvel e descobre-se uma moradia. Uma casa está escondida no cofre" (p.253). Quer dizer que a intimidade do homem agora não está na casa, mas sim nos espaços que fazem parte da casa. Espaços que, também eles, nos fazem encontrar com as nossas recordações, com as nossas lembranças reais ou imaginadas e, por isso, promovem o encontro com nós mesmos.

Os capítulos seguintes, tal como o capítulo três, continuam a ser pontuados por experiências oníricas vividas ou descritas por outros pensadores como Robert Ganzo, Yvan Goll ou Victor Hugo, que falam sobre o bem-estar vivido no aconchego do ninho, da concha, ou dos cantos: "refúgios do vertebrado e do invertebrado" (p. 197). Aqui, o objetivo de Bachelard é mostrar como, nesses espaços primitivos, podemos encontrar uma felicidade física ao sentir prazer quando nos encolhemos nos seus cantos ( $p$.257). Ou seja; o autor evoca imagens de proteção e amor, que também estão presentes na casa, mas aqui, elas estão nos ninhos e nas conchas, que, segundo os poetas, são lugares onde já vivemos mil sonhos aéreos ou aquáticos ( $p$. 197).

Nos últimos três capítulos, e depois de seguir os devaneios de habitar lugares inabitáveis, Bachelard regressa ao mundo das imagens propondo que nos façamos pequenos para vivê-los: "Só mora com intensidade aquele que já soube encolher-se" (p.197). Depois de todos os capítulos dedicados aos espaços de intimidade, o autor quis testar como se apresenta, numa poética do espaço, a compreensão da dialética do grande e do pequeno. As perguntas que, indiretamente, nos coloca são: Como, desde uma posição exterior, se forma uma impressão de imensidão? A imensidão está em nós? Ou está no espaço?

Em definitivo, podemos dizer que, ao longo dos dez capítulos do livro "A poética do espaço", Gaston Bachelard tenta reunir uma vasta coleção de possíveis "imagens do ser, todas as imagens múltiplas, cambiantes que, da mesma forma, ilustram a permanência do ser (...)" (p. 354). Aqui reside a importância deste livro, em especial para os estudantes de arquitetura: entender o modo como Bachelard, através de imagens que evocam reflexões filosóficas e psicológicas, nos aproxima das complexas relações entre homem e espaço, fazendo-nos perceber a influência que o espaço exerce em quem o habita.

\footnotetext{
1 Edição utilizada: BACHELARD, Gaston - Os Pensadores. São Paulo: Abril Cultura, 1979. Tradução de António da Costa Leal e Lídia do Valle Santos Leal.

${ }^{2}$ Gaston Bachelard faz a distinção entre alma e espírito dizendo que: "A consciência associada à alma está mais fundada, menos intencionalizada do que a consciência associada aos fenómenos do espírito" (p. 186).
} 